Bencsik Gábor ${ }^{1}$ - Király László ${ }^{2}$

\title{
A háborús pénzügyi elmélet egyes, máig aktuális kérdései, avagy miből finanszírozzuk a háborút?
}

DOI 10.17047/Hadtud.2020.30.E.154

\begin{abstract}
A történelem sokkal több olyan hadseregröl tud, amelyet a szükösség és a zürzavar bomlasztott szét, mint amit ellenségeik erőfeszítései tettek tönkre, és jómagam voltam szemtanúja annak, hogy minden vállalkozás, amibe az én időmben fogtak, egyedül emiatt bukott meg.
\end{abstract}

Richelieu: Testament Politique

\begin{abstract}
Absztrakt:
A háborús időszakok finanszírozásának kérdése időről időre folyamatosan visszatérő, a nemzetgazdaságra erős befolyással és hatással bíró kérdéseket vet fel. ${ }^{3} \mathrm{~A}$ hadi kiadások előteremtésére ugyan léteznek alternatív megoldások, azonban ezek nem tekinthetők egy win-win helyzetnek az állam és a gazdasági szereplők viszonyának rendszerében. Jelen írásban az elmúlt időszakban látott és tapasztalt megoldásokba, valamint egy félve használt alternatív megoldásba nyújtunk betekintést az olvasó számára.
\end{abstract}

Kulcsszavak:

háborús pénzügyek, hiperinfláció, örökjáradék jellegű hadikötvény

\section{Some of the current issues of theory of war financing (what do we finance the war from?)}

\begin{abstract}
:
The issue of financing the periods of wars raises recurring issues from time to time, with a strong influence and impact on the national economy. Although there are alternative solutions for raising military expenditure, they cannot be considered a winwin situation in the system of relations between the state and economic actors. In this paper, we provide the reader with an insight into the solutions seen and experienced in the recent past, as well as an alternative solution that is used in fear.
\end{abstract}

Keywords:

war finances, hyperinflation, perpetual bond (consol)

\footnotetext{
${ }^{1}$ Nemzeti Közszolgálati Egyetem, Katonai Müszaki Doktori Iskola, doktorandusz - National University of Public Service, Doctoral School of Military Engineering, PhD Student; e-mail: bencsik.gabor@hm.gov.hu; ORCID: 0000-0002-1394-6765

Magyar Hadtudományi Társaság - Hungarian Association of Military Science; e-mail: kiraly.laszlo@uni-nke.hu

${ }^{3}$ Hasonlóan igaz a megállapítás például a különleges jogrend magyarországi bevezetését előidéző COVID-19 néven ismert járványügyi helyzet esetén.
} 
A jelenség, avagy a „háború egyik ára”: a háborús infláció, hiperinfláció

Az amerikai függetlenségi (1775-1783) és az észak-dél háború (1861-1865) idején tapasztalt több százszoros áremelkedést (lásd 1. ábra) mai terminológiával hiperinflációnak ${ }^{4}$ nevezzük. A hiperinflációt, ami többek között az árszínvonal rohamos emelkedésében nyilvánult meg, olyan rendkívüli körülmények váltják ki, mint amilyen általában a háborús időszakok, a súlyos, elhúzódó társadalmi konfliktusok, illetve természeti katasztrófák. Ezen esetekben ugyanis a monetáris hatóság habár (megjegyzésként: hiába) törekszik a piaci szereplők várakozásainak pozitív irányú alakítására, azonban az Adam Smith (skót közgazdász; 1723-1790) által 1776-ban A nemzetek gazdagsága című művében bevezetett "láthatatlan kéz" ellen ezen intézkedések sokszor kevésnek bizonyulnak.

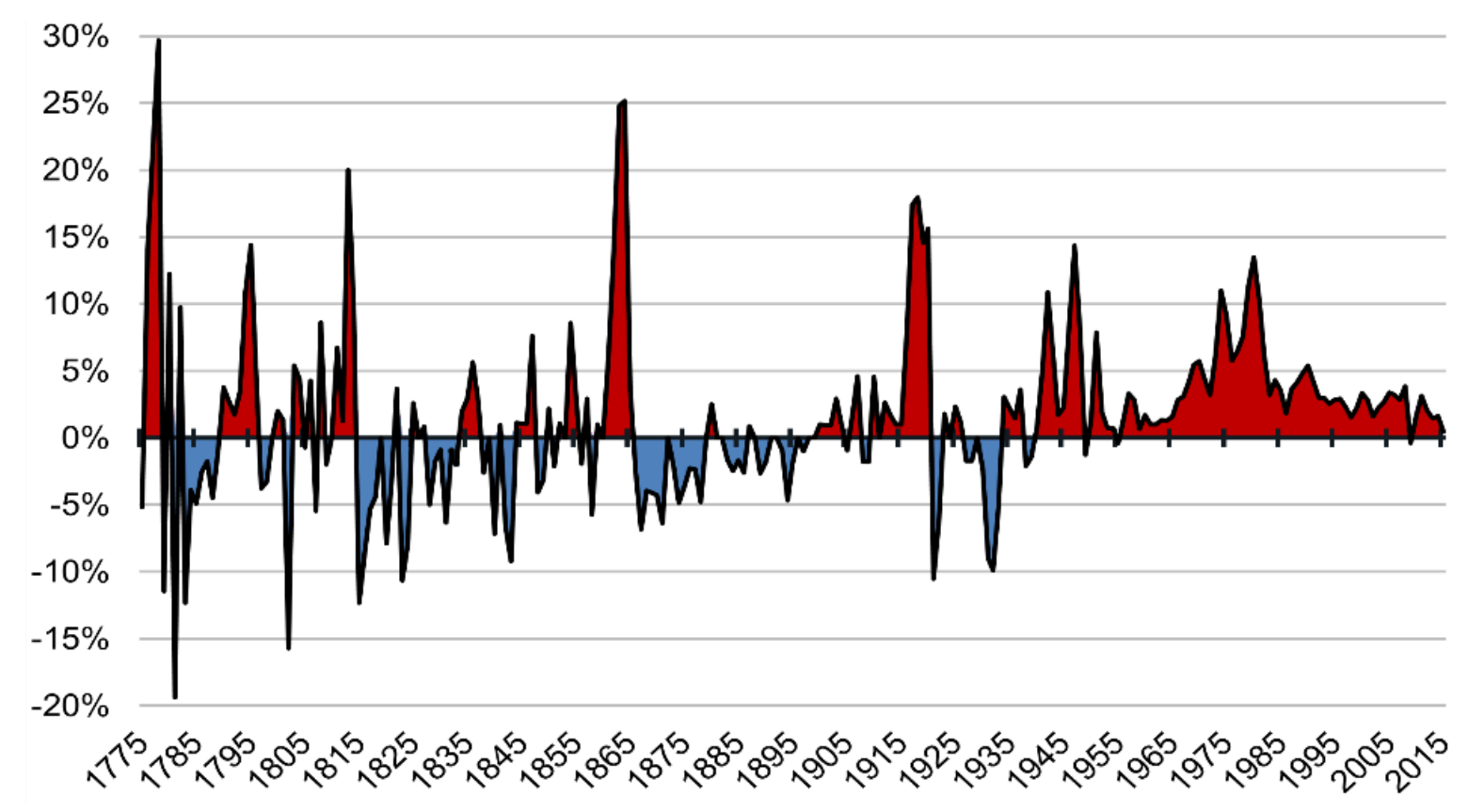

1. ábra

Az Amerikai Egyesült Államok inflációs rátája 1775-töl ${ }^{5}$

Mint Galbács 2012-ben megjelent írásában ${ }^{6}$ olvashatjuk, „[az] inflációs várakozások elszabadulása mindig dilemmát okoz a monetáris hatóságnak, hiszen az inflációs feszültség enyhítésének egyik eszköze olyan kamatdöntés, amely azonban káros reálgazdasági hatásokkal járhat; a reakció elmaradása azonban a várakozások megerősödése miatt az infláció elszabadulását okozhatja, hiszen a munkavállalók és a termelök is hajlamosak lehetnek bérigényeik és árajánlataik

\footnotetext{
${ }_{5}^{4}$ Hiperinfláció: szélsőségesen magas infláció.

${ }^{5}$ Forrás: Josh Zumbrun: A Brief History of U. S. Inflation Since 1775; Dec 14, 2015; online: https://blogs.wsj.com/economics/2015/12/14/a-brief-history-of-u-s-inflation-since-1775/ (Letöltés ideje: 2020. 03. 24.)

6 Galbács Péter: Aktív szabályozás vagy gazdaságpolitikai nihilizmus? (Az újklasszikus makroökonómia gazdaságelmélete - egy kritikai elemzés.) Akadémiai Kiadó, Budapest, 2012. p. 370.
} 
emelésére - a jegybanki cselekvés elmaradása ekkor a magasabb inflációs várakozások helyességéről győzi meg a közönséget (Goodfriend 1993:2).”

A hiperinfláció jelenségét kiváltó, forgalom papírpénzzel való túltelítettsége a háborús időszakok egyik tipikus jellemzője. Ezt a túltelítődést nevezhetjük analóg módon a pénzforgalom felfúvódásának, mely önmagában képes teljesen felborítani az ár- és jövedelmi viszonyok teljes rendszerét. Ilyen periódusokban az árak viharos emelkedésének ismétlődő kiindulópontja, a pénzmennyiség szinte korlátlan növekedése. Az árszintemelkedés formai oka így valóban a pénzoldalon keresendő. Szemben a normális gazdasági körülményekkel, amikor az árszínvonal változásának az oka nem szűkíthető sem csupán a pénzoldalra, sem csupán az áruoldalra, a háborús időszak abnormális gazdasági helyzetében a békés időszak gazdasági törvényei felborulnak, de legalábbis módosulnak.

A gazdaság militarizálása, a speciális igények kielégítése kikényszeríti a termelési struktúra katonai célú átalakítását, lényegében deformálását. A termelési szerkezet hirtelen deformációja elkölthetetlenné teszi a korábban képződött jövedelmek egy részét, amelyek még a békés termelésben kialakult termelési és fogyasztási szerkezetnek megfelelő jövedelemelosztásként születtek. A jövedelemtulajdonosoknál - az államot kivéve - elkölthetetlen pénzfeleslegek képződnek, azaz kényszer-pénzfelhalmozás történik. Ebböl azonban még nem feltétlenül következik a pénzforgalom „papírral” való telítődése, az árak hirtelen és jelentékeny emelkedése. A kínálatot nem találó fizetőképes kereslet különböző pénzügytechnikai eszközökkel elvileg leköthető és az állam javára átcsoportosítható. Ha az állam csak az így kieső keresletet pótolja, és az állam által támasztott kereslet szerkezete éppen megfelel a háborús gazdaság kínálati szerkezetének, a gyors ütemű árszínvonal-emelkedés elkerülése legalábbis nem kizárt.

Csakhogy - a kormánynak nagy bánatára - egyrészt lehetetlen a kínálathoz viszonyított jövedelemfeleslegek maradéktalan átcsoportosítása az állam javára. Másrészt - és ez a lényegesebb tényező - az állami megrendelések révén keletkező újabb és újabb személyes jövedelmek a fogyasztási cikkek piacára áramlanak. A fogyasztási cikkek piacán, éppen a gazdaság háborús átalakítása miatt egyre kevésbé kielégítő a kínálat az aktuális, fizetőképes kereslettel szemben. A megfigyelhető jelenség: túlkereslet, hétköznapi nyelven: hiány. Ennek az oka kézenfekvő: a gazdaság kapacitás-korlátainak köszönhetően egyes fogyasztási cikkek előállítása háttérbe szorul, sőt, annak további jelentős része is katonai jellegűvé válik. A hadiipar gyors fejlesztése elsődlegesen éppen a fogyasztási cikkek rovására történik. Ezen folyamatban a piac - az állam számára - abszolút partnernek tekinthető, tekintettel az érintett piac monopol vagy monopolista jellegére, melynek megfelelően a folyamatban résztvevő piaci szereplők extra profit várományosai lehetnek. Az általános, elsősorban nem hadi-, hanem nemzetgazdaságot kiszolgáló piacon megfigyelhető áruhiány azután a fogyasztási cikkek piacáról fokozatosan, de ellenállhatatlanul átterjed a termelési eszközök, ezen belül főként a nyersanyag és energiahordozók piacára is. 
A hiány fokozódása miatt az árszint viharos emelkedése - kötött árak mellett a feketepiacon - akkor is elkezdődik, ha az állam nem nyúl a korlátlan pénzszaporítás (jegybanki nyomtatás) eszközéhez, ha másrészt nem, akkor a pénz forgási sebességének ugrásszerủ emelkedése miatt. Ha viszont beindul az árszínvonal emelkedése, méghozzá gyorsuló ütemben, akkor az állam - amennyiben a háború folytatódik - akarva-akaratlanul a papírpénz mind növekvő mennyiségi szaporítására kényszerül. A pénzügyi intézményrendszer transzmissziós tevékenysége következtében kibocsátott, ezáltal forgalomban lévő pénz mennyiségének rohamos növekedése a gazdasági stabilitásra, valamint az árstabilitás biztositására jelent kedvezőtlen hatásokat.

A hadigazdálkodásra való átállás és annak állami finanszírozása tipikus improduktív termelés és kiadás. Ez abban az értelemben improduktív termelés és kiadás, hogy a gazdaság müködése szempontjából nem nélkülözhetetlen, miközben eröforrást vesz el és jövedelmet keletkeztet. Az erőforrásoknak a hadiiparba történő túlzott mértékü összpontosítása - eltekintve a kutatás-fejlesztés polgári ágazatokat is serkentő hatásától - mind rövid, mind pedig hosszú távon az eröforrások értelmetlen pazarlásával együtt járó folyamat. A hadiipar produktumai - kivéve persze az exportot - sem közvetlenül, sem közvetve nem járulnak hozzá az életszínvonal növeléséhez, a hadiipar kibocsátása teljes egészében kiesik az újratermelés körfolyamatából. Így minden olyan állami kiadás hosszabb távon súlyos következménnyel jár, amely tehát az elöbbi értelemben improduktív tevékenységet finanszírozza. A mérték persze itt sem mindegy, de ettől is függ, hogy a folyamat átcsap-e hiperinflációba, s ez elvezet-e a teljes összeomlásig.

Összefoglalva tehát az infláció kifejezés keletkezése idején a mai értelemben vett hiperinfláció folyamatát jelölhette. A papírpénzben és az aranyban kialakuló árak kettőssége, vagyis a kettős értékmérés csak átmenetként állhatott fenn. $A z$ a tény, hogy az aranynak a polgárháború alatt ázsiója volt a papírpénzzel szemben, azt igazolja, hogy az arany átmenetileg közönséges áruvá vált. Az arany kicsapódása, a papírpénz tömegének állandó és túlzott növekedése a gazdasági és pénzügyi összeomlás kísérő jelensége. Éppen ebböl következik, hogy formailag csak a pénzoldalra visszavezethető rohanó árszínvonalemelkedés csak rendkívüli általában (polgár)háborús - időszakban következik be. A papírpénz mennyiségének korlátlan szaporodása, a pénzforgalom csatornáinak túltelítődése vagy felfúvódása és végső soron a pénzrendszer összeomlása, ezek alapján a hiperinfláció időszakának kísérő jelensége, illetve eredménye.

\section{A megoldandó probléma - a megoldás egyes útjai, történelmi tapasztalatai}

Ahhoz, hogy ezen, a gazdaságok számára különösen kedvezőtlen folyamatok ne következzenek be, számos megoldandó probléma előtérbe helyezése, vizsgálata és megválaszolása szükséges, mint például:

- a növekvő hadikiadások fedezése és a költségvetési hiány korlátok között tartása; 
- a beruházásoknak a hadiiparba, haditermelésbe áramoltatása;

- a bérek és az árak, a kereslet és a kínálat ellenőrzése, egyensúlyban tartása;

- a hazai valuta elértéktelenedésének megelőzése.

A közgazdaságtanban gyakran (és természetesen indokoltan, nem hiába valóan) hivatkozunk az erőforrások szükösségére, mely egyaránt érinti a keresleti és a kínálati oldalt. Az előző fejezetben láthattuk, hogy a vizsgált probléma megoldására a korlátlan pénzeszköz-kibocsátás sem nyújt kielégítő alternatívát. Láthatjuk tehát, hogy a fő probléma, amivel szemben állunk: az állam számára rendelkezésre álló pénz mennyiségének azonnali, nagy mennyiségủ és minimális haszon-áldozattal járó növelésének kérdése. Célunk tehát az állam hadigazdálkodását támogató pénzmennyiség infláció-mértéket kevésbé növelő előteremtése. Ha a választ a történelem vizsgálatán keresztül szeretnénk megkapni, az alábbi kérdés megválaszolása mentén célszerü elindulnunk: Melyek voltak a hadigazdaságra való áttérés legfontosabb pénzügyi következményei?

Az első világháborúban a hadigazdaság rendkívül nagymérvü inflációval járt együtt, amelynek lényeges szerepe volt a lakosság jelentős részének rohamosan romló életkörülményeiben, olykor nyomorában, és mindinkább növekvő társadalmi elégtelenséget, zavarokat, sztrájkokat, egyes esetekben forradalmakat eredményezett. A második világháború kezdetétől tehát valamennyi hadviselő országnak át kellett gondolnia, miként csoportosítsa át úgy belső erőforrásait, hogy az ne okozzon feloldhatatlan ellentmondást a rendelkezésre álló erőforrások és javak között, s ne járjon együtt a hatalmas áremelkedések miatt a pénz rohamos elértéktelenedésével. A háború alatt az átlagos kereslet lényegében meghaladja a kínálat szintjét, és megfelelő ellenőrzés nélkül bizton tartani lehetett egy nagyarányú inflációs hiány kialakulásától, állandó, nagymérvű áremelkedéstől, amellyel a béremelkedés igyekezett lépést tartani. Ez a veszély - túlmenően társadalmi hatásain - azzal fenyegetett, hogy az ár-bér spirál tovább növeli a hadiköltségeket, s végül is hiperinflációba torkollik.

1940-ben egy tanácskozáson német közgazdászok azt állították, hogy már a békeidőben sikerült megoldaniuk a háborús finanszírozás technikai kérdését. Kétségtelen, ez nem volt puszta dicsekvés. A harmincas években Mefo-váltókkal (német: Mefo-Wechsel, 1934.) ${ }^{7}$ valóban infláció nélkül biztosították a felfegyverkezés pénzügyi szükségleteit. Ez a mechanizmus egészen a háború kitöréséig sikeresen működött. Természetesen ezután lényegesen megváltozott a helyzet, hiszen 1939-től mind a költségvetés, mind a nemzeti termék nagyobb részét fordították hadicélokra, $s$ megkezdődött a tényleges tőkejavak fizikai pusztítása is. Az angol történészek

\footnotetext{
7 Nem-konvencionális állami hitelteremtés, melynek ötlet-háttere, az akkori Német Birodalom gazdasági miniszteri posztját 1934-től betöltő Hjalmar Schacht (1877-1970) megfogalmazása szerint: „Minden olyan terv, amely valamilyen formában szükségessé teszi pótlólagos pénz nyomását, azonnal elutasítandó. A tökét termeléssel vagy takarékossággal kell elöállítani." Idézi: Drábik János: $A z$ inflációmentes pénzkibocsátás és hitelnyújtás - A Lautenbach-memorandum. (Forrás: https://www.slideshare.net/DrabikJanos/drbik-jnos-az-inflcimentes-pnzkibocsts-s-hitelnyits-alautenbachmemorandum p. 7. (Letöltés ideje: 2020. 09.17.)
} 
véleménye szerint Nagy-Britannia háborús felkészülését a kincstár által gyakorolt pénzügyi ellenőrzés is erősen akadályozta, mivel a kincstár részéröl minden olyan gazdaságpolitikát elleneztek, mely ugyan a hadifelkészülés szempontjából szükségesnek látszott, de nemkívánatos pénzügyi következményekkel járhatott, legyen az további költségvetési hiány, fizetési mérleg-nehézség vagy a font értékének csökkenése. Az ugyanis egyértelmű volt, hogy a források újraelosztása, a kereslet és a kínálat egyensúlyhiánya és számos hadicélokat szolgáló cikk termelése elösegítheti a font nemzetközi leértékelödését.

A háború előtt számos vita és nézetkülönbség bontakozott ki arról, miként lehet elkerülni a háború finanszírozásának hagyományos módszerét, s milyen új eszközöket és módokat lehet alkalmazni egy sokkal hatékonyabb háború pénzügyi politikája érdekében. A hagyományos megoldás egyszerü volt: vagy az általános adómérték vagy az államkötvény-kibocsátás növelése. Általában az adózást tartották a kedvezöbb megoldásnak, hiszen ez végleges jövedelmet biztosított, $s$ a jelent, nem pedig a jövő generációját terhelte. Bármilyen hathatós érvek szóltak azonban amellett, hogy a hadikiadásokat mind nagyobb mértékben adóemeléssel kell fedezni, egyre világosabbá vált, hogy a mind bonyolultabb fegyverek költségeit aligha tudja egyetlen ország is tisztán csak saját adójövedelméböl finanszírozni. Az ideálisnak tünő megoldás: a hadikiadások 50\%-át adóból, 50\%-át pedig kölcsönökböl, illetve más pénzügyi műveletekből megoldani, igen kérdésesnek látszott. Amennyire azonban sikerült a németeknek a harmincas években az újrafelfegyverzés pénzügyi igényeit nem hagyományos módszerekkel megoldani, úgy erősödött az a nézet, hogy léteznek olyan új pénzügyi eszközök, amelyekkel egyrészt hatékonyabbá tehető az ország gazdasági erőforrásainak mozgósítása, másrészt megnyílik a lehetőség újabb jövedelemforrásokat előteremtésére. Ezek közé tartozhatott a kincstárjegyek nagyobb mérvü kibocsátása, előlegek felvétele vagy a magán-vásárlóerő felszívása a pénz forgási sebességének meggyorsításával, a rövid, illetve hosszú lejáratú kölcsönök manipulálásával. Mindennek ellenére nem állithatjuk, hogy a háború finanszírozási problémája lényegesen változott az első világháborúhoz képest. A feladat nagysága összehasonlíthatatlanul megnövekedett, a lényeg ugyanaz volt. Fedezni kellett a növekvő hadikiadásokat és egyidejüleg mégis legalább szinten tartani a költségvetési hiányt, a beruházásokat egyértelmüen a hadiiparokba irányítani és egyidejüleg ellenőrizni a béreket és az árakat, egyensúlyban tartani a keresletet és kínálatot, hogy ne értéktelenedjen el a hazai valuta.

Az első, valamint a második világháborús felidézett finanszírozási módszereit összehasonlítva végülis arra a következtetésre kell jutnunk, hogy a hadviselö országok, jóllehet a feladat nehezebb volt, mégis a második világháborúban sikeresebben birkóztak meg vele, mint az első világháború idején. Egyik országban sem tapasztalhatunk - legalábbis a legfontosabb hadviselő országok között - az első világháborúhoz hasonló mértékü inflációt vagy szociális zavarokat. Mégis, az öt legfontosabb hadviselő közül az angol és a (rendkívül radikális, föleg gazdaságon kívüli eszközökre építö) szovjet megoldás tünik a legsikeresebbnek, hiszen ezekben 
az országokban, annak ellenére, hogy rendkívül nagy volt az egyensúlyhiány a kereslet és a kínálat között, a különböző kormányintézkedésekkel sikerült kiküszöbölni a túlságosan nagy pénzkeresletet, s a folyamatot a rejtett infláció keretei között tartani. ${ }^{8}$

A felvázolt folyamatokból is jól látszik, hogy a felvetett probléma, vagyis a háború valamilyen módon történő finanszírozása igen komplex kérdéseket helyez előtérbe. $A$ háborúnak ára van, a költségeket pedig valaki(k)nek viselnie kell. A kérdés csupán az, hogy: ez a költségviselés a jelenben vagy a jövőben valósuljon meg? Mindkét megoldás mellett felsorakoztathatóak pro és kontra érvek. Adam Smith $A$ nemzetek gazdagsága című művében kiemeli: „Talán nincs olyan önző érdek, mely annyira komolytalan lenne, hogy hajszolása olykor még az értelmes embereket sem tette tönkre." Láthatjuk tehát, hogy az ember gazdasági életének fő motívuma az önző érdek. Ebben az esetben nyilvánvaló, hogy a háború szükségszerü, azonban annak költségviselése elodázandó. A megoldás tehát, mellyel saját érdekeit nem sérti, vagyis háború finanszírozásához szükséges pénzügyi erőforrás jelenben történő megteremtését nem a gazdaságban lévő pénz mennyiségi növelésén keresztül hajtja végre, így a reálgazdasági érdekei nem sérülnek (olyan mértékben): a soha le nem járó (örökjáradék jellegű) kötvény ${ }^{10}$ (angolul: perpetual bond; consol) kibocsátása.

$A z$ (egyszerűen rövidítve csak:) örökjáradék, mint speciális pénzáram, nem egy újkeletü pénzügyi instrumentum és nem is a háborúk, vagy azok finanszírozásának folyamatosan visszatérő kérdésköre hívta/hívták életre. Gazdasági megalapozottsága a vállalati pénzügyek mezején keresendő és található. $A z$ örökjáradék lényege, hogy egy maghatározott piaci kamatláb ismeretében egy elöre rögzített pénzösszegért cserébe életünk végéig fix (vagy változó ${ }^{11}$ ) összegű pénzáramra vagyunk jogosultak. Az elmélet alapján:

$$
\text { Hozam (r) }=\frac{\text { Járadéktag (C) }}{\text { Jelenérték (PV) }}
$$

\footnotetext{
${ }^{8}$ A pénzügyi és a gazdaságon kívüli szabályok arányairól és szerepéről lásd bővebben: Alan $\mathrm{S}$. Milword: Háború, gazdaság, társadalom 1939-1945. Aquila Könyvkiadó, Budapest, 2000. pp. 124160.

${ }^{9}$ Eredeti szöveg: „There is not, perhaps, any selfish pleasure so frivolous of which the pursuit has not sometimes ruined even sensible men." In: Adam Smith: An Inquiry Into The Nature and Causes of the Wealth of Nations (Books I, II, III, IV and V); MetaLibri, 29th May 2007; Chapter III: of public debts; G. ed. p. 907.; online: https://www.ibiblio.org/ml/libri/s/SmithA WealthNations p.pdf (Letöltés ideje: 2020. 05. 17. A szöveget magyarra fordították: a szerzők.)

${ }^{10}$ Megjegyzendő, hogy egy olyan időszakban, amikor a háború bekövetkezésének valószínűsége magas, illetve egyes államok már el is kezdték a háborúra történő felkészülést, csekély az esély arra, hogy a nemzetközi tökepiacokon a kötvényhozamok alacsony szinten tarthatóak, melynek köszönhetően ezen finanszírozási formának is vélhetően magasabb az „ára” (összköltsége), mint ha békeidőszaki hozamértékkel számolnánk.

${ }^{11}$ A fix és a növekvő tagú örökjáradékokkal kapcsolatban lásd részletesen (a müködési mechanizmus bizonyítását is tartalmazó): Brealey-Myers: Modern vállalati pénzügyek. Budapest, Panem Kft., 2005. pp. 39-40.
} 
Ha az imént felvázolt képletet egy kicsit átrendezzük, máris megértjük, miért nyújt kiváló alternatívát a hadikiadások (reálgazdaságot kevésbé sújtó) finanszírozására:

$$
\text { Jelenérték (PV) }=\frac{\text { Járadéktag (C) }}{\text { Hozam (r) }}
$$

Látható tehát, hogy egy, az aktuális piaci hozamot (kamatlábat) figyelembe vevő mértékü hozam-szám ( $r$ ) alkalmazása esetén meglehetősen kedvező jövöbeni bevételforrás (pénzáram) érhető el a piaci szereplők (főként befektetők) számára. Különösen igaz ez magas kamatkörnyezet esetén. Szintén ezen állítást támasztja alá Zsiday Viktor 2012-ben megjelent írása, melyben kifejti: „Százéves vagy akár még hosszabb, örökjáradék-kötvényeket bocsátana ki a brit kincstár, kihasználva az évtizedes mélyponton lévő pénzpiaci hozamokat. Nyugodtan kijelenthetjük, hogy ez bizony az évszázad lehetösége - de nem a befektetöknek, hanem a brit államnak."12 Megállapíthatjuk tehát, hogy alacsony kamatkörnyezetben ${ }^{13}$ az állam számára legkedvezőbb (a gazdaságban lévő pénz mennyiségét nem emelö, így a reálgazdaságot kevésbe (vagy egyáltalán nem) károsító) megoldás az állami pénzeszköz-oldal azonnali felpumpálására az örökjáradék jellegü kötvény kibocsátása.

\section{A megoldandó probléma egyes aktuális kérdései}

Az örökjáradék jellegủ hadikötvény kibocsátását ugyan elfogadható és alternatív megoldásnak tekinthetjük, azonban az állam vs. gazdasági szereplők helyzetét tekintve egyáltalán nem beszélhetünk win-win állapotról. Valaki jól jár, valaki rosszul. A pozíció az éppen aktuális kamatkörnyezet által determinált. Az itt közölt szemelvényekböl ezáltal az a következtetés vonható le, hogy nincs olyan általános recept, amelyet jelenleg a gazdaság védelmi felkészítése során egy háborús konfliktus esetén várható pénzügyi problémák elöre tervezett módon való kivédésére használhatnánk.

Ennek alapja és okai:

- a doktrínából (védelmi alapelvek) adódóan védelemre rendezkedünk be és a maximális hadászati célkitúzésnek tekinthetjük egy támadást követően az eredeti helyzet visszaállítását;

- a védelem, a támadók-védők klasszikus 3:1 erőviszonyát feltételezve, alacsonyabb költségszinten biztosítható;

\footnotetext{
${ }^{12}$ Zsiday Viktor: Az évszázad befektetése; 2012. március 19. 10:58; online: https://alapblog.hu/azevszazad-befektetese (Letöltés ideje: 2020. 05. 17.)

${ }^{13}$ Két példát összehasonlítva az eredmény értelmezhetővé tétele érdekében az egységes állami bevétel (jelen esetben: PV) elérését célszerü célként meghatároznunk. Ekkor a fenti képletek alapján: Jelenérték (PV): 100 000; elvárt hozam: 10\% esetén az évente várható örökjáradék összege (C): 10 000; Jelenérték (PV): 100 000; elvárt hozam: 4\% esetén az évente várható örökjáradék összege (C): 4000 .
} 
- a biztonságpolitikai helyzet, az integrációs folyamatok ellene hatnak és szükségtelenné (spekulatív kérdéssé) teszik a felvetett probléma ilyen aspektusú vizsgálatát;

- a gazdaság védelmi felkészítése alapelvei között „a priori” feltételezés volt, hogy a jól müködő piacgazdaság tudja biztosítani mindazon forrásokat és anyagi javakat, amelyek a védelmi felkészüléshez és az első védelmi harc megvívásához szükségesek. Ebből következik, hogy minden gazdaság stabilitását, az egyensúlyi növekedést és az inflációs folyamatok visszaszoritását szolgáló lépés egyben a felvetett probléma megoldásához is hozzájárul.

Ami a fentieken túl rendelkezésre áll, az a rendkívüli időszakban alkalmazható jogszabályok halmaza. Ez olyan elökészített, de ki nem hirdetett jogszabályokat jelent, amelyeket a különleges jogrenden alapuló hatalomgyakorlás időszakában hirdetnek ki.

A gazdaságra vonatkozóan, fenntartva a minimális beavatkozás elvét, ezek a következők:

- az állam rendelkezésére álló erőforrások (költségvetés) körében végzett átcsoportosítás;

- a védelem céljára bevonható erőforrások növelése (adózás háborús szabályai);

- gazdasági anyagi szolgáltatások igénybevétele (pl. nemesfém és devizaforgalom korlátozása és kötelező vételre felajánlás, banki és értékforgalmi korlátozások).

\section{Összefoglalás}

Írásunkban számos alternatív megoldásba nyújtottunk betekintést, melyek egytöl egyig a háborús időszakok természetes velejárójaként tekinthető, állami oldalról (finanszírozási problémaként) tapasztalható, azonban közvetve és közvetett módon a nemzetgazdaságot is jelentősen érintő pénzhiány kezelését érintik. Láthattuk, hogy a történelem során az egyes országok különböző módon próbálták meg az időszaki többletkiadásaikat finanszírozni, azonban egységes álláspont a témakört érintően ezidáig nem született. A felvázolt és bemutatott örökjáradék jellegú hadikötvény a vállalati pénzügyek területén ismert klasszikus örökjáradékként aposztrofált speciális pénzáram, mely „az idők végezetéig állandó [szerzői kieg.: vagy meghatározott ütemü növekedéssel emelkedö] összegü pénzáramlást biztosit". ${ }^{14}$ Említés szinten érintettük, hogy habár maga a konstrukció zseniális, egyértelmű alkalmazásának korlátja a win-win helyzet hiányában keresendő, mely a megszokottól eltérő kamatkörnyezet és annak kiszámíthatatlan volta generál. ${ }^{15}$

\footnotetext{
${ }^{14}$ Brealey-Myers: Modern vállalati pénzügyek. Panem Kft., Budapest, 2005. p. 39.

15 Galbács Péter: Aktív szabályozás vagy gazdaságpolitikai nihilizmus? (Az újklasszikus makroökonómia gazdaságelmélete - egy kritikai elemzés.) Akadémiai Kiadó, Budapest, 2012.
} 
Felmerülhet az olvasóban a kérdés, hogy vizsgálatunkat miért nem terjesztjük ki a második világháború óta eltelt időszakra. Valóban, a kétpólusú világrend közel fél évszázadában számos a nagyhatalmak által generált helyi háború zajlott le, amelyek azonban rendkívül eltérő hatást gyakoroltak mind az azt elszenvedő államok, mind a vezető nagyhatalmak (USA, Szovjetunió) gazdaságára. Mindez azonban túlterjeszkedne a cikk tartalmi és terjedelmi keretein. Hasonló okokból nem térünk ki az Iszlám Állam háború-finanszírozási filozófiájának és gyakorlatának elemzésére, vagy a kibertérben megjelent és terjedő virtuális pénzek (bitcoin) lehetséges szerepére.

Utolsó megválaszolandó kérdésként pedig felmerülhet bennünk: melyik modellt lenne célszerủ alkalmazni egy esetleges háború, vagy háborúhoz nagyon hasonló esemény bekövetkeztekor? Melyik modell szolgálná legjobban az állam, a nemzet és a befektetők érdekeit? A válasz megfogalmazásához Václav Havel (1936-2011) cseh köztársasági elnök (1993-2003) egykori gazdasági tanácsadójának, a cseh sztárközgazdász, Tomáš Sedláček (1977-) szavait idézzük, miszerint: „Minket, közgazdászokat pedig arra tanitottak, hogy lehetöség szerint ne mondjunk egyértelmü itéletet, véleményt arról, hogy mi jó, és mi rossz."16

${ }^{16}$ Tomáš Sedláček: A jó és a rossz közgazdaságtana (A Gilgames-eposztól a Wall Streetig), HVG Kiadó Zrt., Budapest, 2012. p. 20. 


\section{FELHASZNÁLT IRODALOM}

Brealey-Myers: Modern vállalati pénzügyek. Budapest, Panem Kft., 2005.

Drábik János: Az inflációmentes pénzkibocsátás és hitelnyújtás - A Lautenbachmemorandum. $\quad$ https://www.slideshare.net/DrabikJanos/drbik-inos-azinflcimentes-pnzkibocsts-s-hitelnyits-a-lautenbachmemorandum

Galbács Péter: Aktív szabályozás vagy gazdaságpolitikai nihilizmus? (Az újklasszikus makroökonómia gazdaságelmélete - egy kritikai elemzés.) Akadémiai Kiadó, Budapest, 2012.

Milword, Alan S.: Háború, gazdaság, társadalom 1939-1945. Aquila Könyvkiadó, Budapest, 2000.

Sedláček, Tomáš: A jó és a rossz közgazdaságtana (A Gilgames-eposztól a Wall Streetig), HVG Kiadó Zrt., Budapest, 2012.

Smith, Adam: An Inquiry Into The Nature and Causes of the Wealth of Nations (Books I, II, III, IV and V); MetaLibri, 29th May 2007; Chapter III: of public debts; G. ed. p. 907.; online: https://www.ibiblio.org/ml/libri/s/SmithA WealthNations p.pdf

Zumbrun, Josh: A Brief History of U. S. Inflation Since 1775; Dec 14, 2015; online: https://blogs.wsj.com/economics/2015/12/14/a-brief-history-of-u-s-inflation-since$1775 /$

Zsiday Viktor: Az évszázad befektetése; 2012. március 19. 10:58; online: https://alapblog.hu/az-evszazad-befektetese 